NBER WORKING PAPER SERIES

\title{
LIBERALIZED PORTFOLIO CAPITAL INFLOWS IN EMERGING MARKETS: STERILIZATION, EXPECTATIONS, AND THE INCOMPLETENESS OF INTEREST RATE CONVERGENCE
}

Jeffrey A. Frankel

Chudozie Okongwu

Working Paper No. 5156

\section{NATIONAL BUREAU OF ECONOMIC RESEARCH 1050 Massachusetts Avenue \\ Cambridge, MA 02138 \\ June 1995}

This paper is forthcoming in the International Journal of Finance and Economics, vol. 1, no. 1, January 1996. It was originally written for a session at the American Finance Association meetings, co-sponsored by the International Economics Department of the World Bank, in Washington, DC, January 6, 1995. The authors would like to thank Alan Kackmeister for intensive and invaluable research assistance. They would further like to thank Carmen Reinhart for much useful discussion and help; the World Bank, Salomon Brothers, Merrill Lynch, and Menzie Chinn of UC Santa Cruz for data; William Cline, Sebastian Edwards, and Eduardo Fernandez-Arias for comments; and the World Bank and the Institute of East Asian Studies at the University of California, Berkeley. The paper was written while Frankel was a Senior Fellow at the Institute for International Economics, Washington, DC. This paper is part of NBER's research programs in International Finance and Macroeconomics and Monetary Economics. Any opinions expressed are those of the authors and not those of the National Bureau of Economic Research.

(C) 1995 by Jeffrey A. Frankel and Chudozie Okongwu. All rights reserved. Short sections of text, not to exceed two paragraphs, may be quoted without explicit permission provided that full credit, including $\odot$ notice, is given to the source. 


\title{
LIBERALIZED PORTFOLIO CAPITAL INFLOWS IN EMERGING MARKETS: STERILIZATION, EXPECTATIONS, AND THE INCOMPLETENESS OF INTEREST RATE CONVERGENCE
}

\begin{abstract}
The paper examines interest rates in nine Latin American and East Asian countries during the period 1987-1994. The goal is to discover why interest rates have remained high, failing to converge to U.S. levels, despite capital market liberalization and a resurgence of portfolio capital inflows during the second half of this sample period. Related questions are whether portfolio capital flows are strong enough to equalize expected returns between these "emerging markets" and the U.S., and whether there is any scope left for the authorities to sterilize inflows. The conclusion of the study is that the largest single component of the gap in interest rates is expectations of depreciation of the local currencies against the dollar. Key to the analysis is the use of survey data on exchange rate forecasts by market participants. Indicative of integrated financial markets, we also find a big effect of U.S. interest rates on local interest rates and a highly significant degree of capital flow offset to monetary policy.
\end{abstract}

Jeffrey A. Frankel

Department of Economics

University of California

Berkeley, CA 94720

and NBER
Chudozie Okongwu

Department of Economics

University of California

Berkeley, CA 94720 


\section{Executive Summary}

We examine portfolio capital inflows in a set of nine Latin American and East Asian countries during the period 1987-1994, focusing particularly on Argentina, Chile, Mexico, the Philippines, and Korea. The analysis resembles other recent studies of inflows, and earlier studies of sterilization and offset coefficients. The most important innovation methodologically is the use of a measure of exchange rate expectations from survey data on the forecasts of market participants. (The source is Currency Forecasters' Digest. The quarterly portfolio capital flow data were obtained from the World Bank's International Economics Department.)

We reach a number of conclusions. First, U.S. interest rates are a very major influence in the emerging markets. Whether one looks at the effect on portfolio capital flows or the effect on local interest rates, it is high and significant. Indeed, changes in U.S. interest rates seem to have an effect on local interest rates that is more than one-for-one. This confirms the finding of Calvo and others that low world interest rates were a major factor in the large capital inflows of 1990-1993. Vulnerability of these markets to increases in U.S. interest rates, such as took place in 1994, could have been (and was) predicted.

Second, there is a substantial offset to monetary policy: the estimate suggests for Mexico that a monetary expansion is followed by a capital outflow within the same quarter equal to 0.28 per cent of the increase in the monetary base.

Third, country risk and remaining capital controls were not the major reasons why interest rates in recipient countries remained above U.S. interest rates in 1990-94. To be sure, country risk, measured for example by the discount in the secondary debt market, is a significant determinant of interest rates. But a decomposition of interest differentials shows that the currency premium is generally larger than the country premium. When countries have difficulty sterilizing inflows, in the sense that the issue of domestic bonds drives up the local interest rate, the interest differential is interpretable in large part as compensation for fears of future depreciation.

Fourth, Mexican interest rates during the period June 1993 - December 1994 were adversely affected by both increases in U.S. interest rates and political events in Mexico. The effects show up both in Mexican dollar-denominated interest rates (tesobonos) and pesodenominated rates (CETES).

It is useful to look at local dollar-denominated interest rates when they are available, to measure the country premium, i.e., the spread over U.S. dollar interest rates. Nevertheless it can be dangerous to look only at dollar interest rates. Econometricians who do so in studies of sterilization and offset are missing the currency premium. For policy-makers to focus too heavily on local dollar-denominated interest rates can be even more dangerous. After the capital flows to Mexico began to reverse in February 1994, the Mexican response was sterilized intervention of the reserve outflows. Anyone who judged the success of this response by looking at tesobono interest rates underestimated the magnitude of the problem. The increase in peso interest rates was much greater than the increase in dollar interest rates in Mexico, signifying a large increase in the currency premium and, as we now know, a lack of sustainability in the exchange rate policy. 


\section{Liberalized Portfolio Capital Inflows in Emerging Markets: Sterilization, Expectations, and the Incompleteness of Interest Rate Convergence}

Six or seven years into the debt "crisis" of 1982, many observers had begun to despair that voluntary capital flows into developing countries would ever resume, other than to some East Asian countries that had not been badly hit by the debt crisis to begin with. After 1989, however, the situation dramatically reversed. Beginning in 1990 (and perhaps ending in 1994), capital flows, much of them taking the form of portfolio investment, flooded into emerging markets, not only in East Asia, but in Latin America and many other parts of the world as well. $^{1}$

\section{Attempts to Sterilize Reserve Inflows}

In economics, any change tends to have both a good side and a bad side. Capital inflows, in addition to their benefits, create some difficulties for the recipient countries in the form of real appreciation of their currencies. These difficulties include a loss of competitiveness by exporters, and the undermining of a strategy to achieve monetary stability by pegging the exchange rate. Indeed, many East Asian and Latin American countries experienced real appreciation during the period 1990-1994. Many tried to resist to some degree such pressure, through sterilized foreign exchange intervention. In other words, the central banks absorbed increases in foreign exchange reserves, in order to resist any tendency toward nominal appreciation, while simultaneously reducing domestic credit in order to resist

1 The trend was identified and analyzed early on by Calvo, Leiderman and Reinhart (1993). Recent reviews of the inflows and the response options for local authorities include Calvo, Leiderman and Reinhart (1995), Fernandez-Arias and Montiel (1995), Goldstein (1995) and Williamson (1994). 
the tendency toward inflationary increases in the money supply.

The reduction of domestic credit can take the form of sterilization defined either narrowly or broadly. Sterilization narrowly defined is the offsetting of reserve inflows so as to leave the monetary base unaffected, for example through the sales of domestic bonds. Sterilization defined more broadly defined is the offsetting of inflows so as to leave the overall money supply unaffected, for example through increases in reserve requirements placed on commercial banks. Either way, successful sterilization will inevitably put upward pressure on interest rates, in the sense that the market interest rate will be higher than it would have been if no attempt had been made to sterilize the foreign exchange intervention, and the reserve inflow had instead been allowed to increase the money supply. Higher interest rates will in turn make domestic assets more attractive to world investors than they would otherwise be, and thus prolong the capital inflow. Calvo (1991) has warned of the difficulties posed by sterilization of inflows. He particularly emphasizes the future budget difficulties that will be created when the government has to pay interest rates on domestic bonds sold by the central bank that are higher than the interest rates earned by the central bank on its holdings of foreign reserve assets.

None of these consequences of capital inflows, or of the policy response to them, is surprising. What would be surprising would be a finding that sterilized capital inflows have raised interest rates in some Latin American countries, not just relative to what they would be without the sterilization attempts, but relative to what they would be without the capital inflows. Capital inflows should put downward pressure on local interest rates. Warnings about the perils of sterilization might be interpreted as claims that interest rates are pushed up relative 
to their position before the capital inflow. This is unlikely to occur in standard models if the cause of the capital inflow is external, for example, a decline in world interest rates such as occurred from 1990 to 1993 or an increased demand for portfolio diversification among U.S. investors, or if the cause is the removal of previously existing barriers to capital inflows. But it would be perfectly natural for local interest rates to rise if the cause of the capital inflow were domestic, for example an investment boom in response to domestic deregulation or in response to successful debt-reduction, or an increase in the local excess demand for money in response to domestic monetary stabilization. ${ }^{2}$

It is logically possible, in a model with several domestic assets, that sterilization of the reserve effects of foreign purchases of domestic assets (say, equities) could lead to higher interest rates on government securities (sterilization bonds), if the bonds issued by the central bank are very poor substitutes for the assets facing the increase in demand. This refinement does not seem to be what Calvo has in mind. But it is an interesting enough possibility to be worth testing for.

\section{Recent Studies of Capital Inflows}

A number of candidates have been offered to explain the upsurge in capital inflows from 1990 to 1993 . Some are purely external, some purely domestic, and some in between. The external factors were a decline in the expected rates of return that were available in the major industrialized countries during the recessionary period 1990-93, particularly the decline in U.S. interest rates. Purely internal factors were domestic economic reforms, including

\footnotetext{
2 These basic textbook points are further elucidated in Frankel (1994).
} 
deregulation, privatization, and monetary stabilization programs (often based on pre-announced exchange rate targets), as well as political evolution toward democracy. Intermediate factors that facilitated the flow from saver country to borrower country include the removal by many countries of controls on capital inflow, debt-reduction under the Brady Plan which was launched in 1989, and institutional innovations in the investor community that made diversification into emerging markets more convenient (such as country funds, American Depository Receipts, and Global Depository Receipts).

A number of recent econometric studies have investigated the causes of portfolio capital investments in major Latin American countries and other key emerging markets during the 1990s. Some details on the techniques used in five studies are summarized compactly in Table 1. Calvo, Leiderman and Reinhart (1993) examine flows to ten American countries during the period 1988-1991. Chuhan, Claessens and Mamingi (1994) examine U.S. purchases of securities in 9 Latin American and 9 Asian countries during 1988-92. Fernandez-Arias (1994) examines portfolio capital flows in a panel of 13 countries, 1989-93.

Perhaps surprisingly, these studies reach something of a consensus, in that all conclude that external factors were a major cause, perhaps the major cause, of the recent capital flows. (Fernandez-Arias emphasizes that the decline in U.S. rates of return, in addition to reducing the opportunity cost of investing in the emerging markets, also improved country creditworthiness as measured by secondary debt prices.) Calvo, Leiderman and Reinhart (1993, p. 136-137) find that "foreign factors account for a sizeable fraction (about 50 per cent) of the monthly forecast error variance in the real exchange rate...[and]...also account for a sizeable fraction of the forecast error variance in monthly reserves." They warn that "The importance 
of external factors suggests that a reversal of those conditions may lead to a future capital outflow." Chuhan, Claessens and Mamingi (1994) estimate that U.S. factors explain about half of portfolio flows to Latin America, though they explain less than country factors in the case of East Asia. Fernandez-Arias finds that the fall in U.S. returns was the key cause of the change in capital flows in the 1990s. Dooley, Fernandez-Arias and Kletzer (1994), in a study of the determinants of the increase in secondary debt prices among 18 countries since 1986, conclude that "International interest rates are the key underlying factor." It is worth emphasizing that all these papers were written during a period when most analysts in the investment community continued to believe that the capital inflows were based on local promarket reforms and were therefore likely to continue. In other words, they (and the first draft of the present paper) were written before the Mexican crisis of December $1994 .^{3}$

\section{The Aims of the Paper}

We now come to a central question to be addressed by this paper. Why did interest rates in most emerging markets fail to converge to world levels? If the cause of the portfolio capital inflows was indeed primarily external, as the econometric studies seem to suggest, then

${ }^{3}$ The steep rise in U.S. interest rates that took place during the course of 1994 constituted a test of the warning, which most of these studies carried, explicitly or implicitly, that an adverse shift in world financial conditions could lead to an abrupt halt to the inflows and a new crisis on the order of 1982. Asset prices in emerging markets did fall on the occasion of the initial tightening by the Federal Reserve Board in February 1994. In many cases the decline in local asset prices was greater than the decline in securities prices in the United States, perhaps because many of the investors who had been holding the assets had been highly leveraged. Asset prices subsequently recovered, as healthy positive capital inflows resumed. The Mexican crisis that began December 20, 1994, however, and the apparent negative effects on securities prices in emerging markets worldwide, seemed to be precisely the sort of crisis about which Calvo and the others had warned. 
local interest rates should have declined. To be sure, nominal interest rates in most of the countries where market-determined interest rates are available were indeed lower after 1990 than previously. ${ }^{4}$ But they failed to decline to the levels in the United States or other industrialized countries. Similarly, real interest rates failed to converge to U.S. levels in most of these countries. ${ }^{5}$

Evaluating these issues is made difficult by exchange rate considerations. There is no question that high nominal interest rates in many emerging market countries include a premium to compensate investors for the likelihood of currency devaluation or depreciation. When we speak of the effect of capital inflows on local returns, or on differentials vis-a-vis the United States, we should be thinking of expected total returns, for example, nominal returns minus expected currency depreciation. It is harder to tell whether expected returns in these countries declined after 1990, and whether expected returns remain above U.S. levels, than would be the case for nominal returns. Expectations of changes in the exchange rate are of course not directly observable.

One suspects that expected depreciation was much smaller in some of these countries after 1990 than it was previously. Many of them, as part of monetary stabilization programs,

\footnotetext{
${ }^{4}$ One exception is Colombia, where interest rates rose in 1990 and 1991, and then fell abruptly in 1992 when sterilization ended. This case has drawn a lot of attention, and is in part the basis for concerns over the perils of sterilization. An alternative explanation that has been offered for this episode is that the source of the capital inflows in those years was a domestic investment boom (Edwards 1991).

5 We choose in this study to focus on nominal interest rates and expectations of exchange rate changes, because these are the variables that are properly of interest to a portfolio investor who is comparing expected returns in different countries. Expected inflation rates are not directly relevant for the decision how to allocate the portfolio among different countries' bonds, except to the extent they influence nominal interest rates and exchange rate expectations.
} 
deliberately slowed down or stopped a previous policy of currency depreciation. Some, most completely Argentina, re-pegged their currencies to the U.S. dollar. As already noted, the post1990 capital inflows put upward pressure on currencies, even where governments would have preferred to avoid real appreciation. Despite doubts about the sustainability of overvalued currencies, it is quite likely that expected depreciation in Latin America has generally been smaller in the 1990 s than in the 1980 s. Thus we cannot say, looking only at nominal interest rates, whether expected returns have indeed fallen.

This paper attempts to quantify the extent to which some key countries in Latin American and East Asia have become open to international capital flows. The analysis begins with simple tests of interest rate parity. We then progress to more elaborate tests of the relationship between portfolio capital inflows and expected return differentials. The final goal is to estimate an "offset" equation that determines portfolio capital flows as a function of domestic credit creation.

An important null hypothesis that will be considered throughout is that the level of barriers to international capital mobility is sufficiently low and the degree of substitutability between domestic and foreign assets is sufficiently high, that arbitrage equates domestic and foreign expected rates of return. In this case, the government loses monetary control, because reserves flow in through the capital account just as fast as domestic credit is extinguished by the central bank. In other words, sterilization is not difficult; rather it is impossible.

\section{How Should We Measure Exchange Rate Expectations?}

Estimates of sterilization and offset equations for Mexico and Colombia include Cumby 
and Obstfeld (1983), Kamas (1985, 1986), and Rennhack and Mondino (1988). Studies for East Asian countries include Fry $(1993,1994)$. Traditionally, the greatest econometric difficulty has arisen from the simultaneity of the sterilization and offset equations: an observed positive relationship between domestic monetary tightening and capital inflows could exist either because capital inflows are attracted by the higher interest rates, or because monetary tightening is the central bank's attempt to sterilize reserve inflows. Studies have emphasized the importance of using simultaneous-equations estimation techniques to disentangle these two effects. $^{6}$

We would argue, however, that an equally great econometric problem is created by the difficulty of measuring exchange rate expectations. Three methods have in the past been attempted for measuring expectations of depreciation or devaluation. The first method is simply to ignore the problem, in effect to assume that investors anticipate no exchange rate changes. This approach is not satisfactory. The second method (e.g., Cumby and Obstfeld, 1993) is to use a forward or futures exchange rate. Aside from the fact that these forward and futures markets do not yet exist for most developing countries, this technique is conceptually flawed. The forward rate only reflects expectations if domestic-currency assets are perfect substitutes for foreign-currency assets, so that there is no exchange risk premium. But perfect substitutability is not especially likely for these countries, a priori, given the magnitude of uncertainty regarding the exchange rate. Furthermore, perfect substitutability is one of the propositions that we wish to test, particularly if we are to study the scope for sterilization. Thus we cannot presuppose it.

6 Kouri and Porter (1974) is typical of earlier single-equation studies of capital account offset. 
Rodriguez (1994) argues that most credit in Latin America is now in dollars, and so the researcher is fully justified in using local dollar interest rates as the way to address the exchange rate issue. ${ }^{7}$ But this ignores the sterilization question. Sterilized intervention changes the mix of peso and dollar assets that investors must hold in their portfolio, not the mix of domestic-issued vs. foreign-issued assets per se. To test its effects we must look at the expected rates of return on peso vs. dollar assets. (This is not to deny that domestic dollardenominated rates of return may be as important a determinant of capital inflows as the expected rates of return on peso assets. A complete analysis would allow fully for both pesodenominated and dollar-denominated local rates of return.)

The third method for measuring currency expectations that is in common use is to infer them from observed movements in actual exchange rate changes (either lagged, in an adaptive or distributive lag formulation, or led, in a rational expectations formulation). But this method is not very reliable even in the context of floating exchange rates, where the distribution of exchange rates is relatively smooth. It is even less likely to give the right answer in the context of developing-country currencies that are prone to large discrete changes in value. This is the original "peso problem." Schadler, Carkovic, Bennett, and Kahn (1993), for example, try in their study of the capital flow offset equation to estimate ex ante expectations from ex post realizations, and are unsuccessful: The coefficients on expectations are either of the wrong sign or statistically insignificant.

3 A study of the determinants of local dollar interest rates, such as Rodriguez (1994) favors, becomes very close to a traditional "country-risk" sort of study of the spread over LIBOR that countries are charged for loans. [E.g., Edwards (1986), or Cline (1995) for bond spreads, who, interestingly, finds that countries that underwent Brady Plan debt reduction now have to pay higher interest rates than those that did not.] 
Here we estimate exchange rate expectations from survey data on the forecasts of market participants. Currency Forecasters' Digest (recently acquired by the Financial Times Group), collects forecasts of future exchange rates from multinational companies and forecasting services. Among developing countries, Argentina, Brazil and Mexico are covered monthly; Malaysia, Philippines, Singapore, Taiwan, Korea, Colombia, and Venezuela are covered bi-monthly; and some others are covered three times a year. Much of this data has been used for other purposes in Chinn and Frankel (1994b) and Frankel and Chinn (1993). These two papers establish that expectations as inferred from the survey data behave very differently from expectations as inferred from ex post changes in the exchange rate under the orthodox rational expectations methodology. ${ }^{8}$ These data have, to our knowledge, not previously been used in the context of capital flows to developing countries.

The exchange rate forecasts are usually compiled on the fourth Thursday of each month. Our data set runs from February of 1988 to June of 1994 . The survey respondents are reported to number approximately 45 , of whom two-thirds are multinational firms and the remainder forecasting firms or the economics departments of banks. We use as the measure of expectations the "consensus forecast" that $\underline{\text { CFD }}$ emphasizes. This measure is the harmonic mean:

$$
\overline{X_{h}} \equiv \frac{1}{\sum_{i=1}^{n} w_{i}\left(\frac{1}{X_{i}}\right)}
$$

${ }^{8}$ In particular, expected depreciation as measured by the survey data obeys a much more sensible relationship to the forward discount than does expected depreciation as measured by ex post changes, which notoriously point in the opposite direction on average. This point was first made by Froot and Frankel (1989), in the context of major industrialized countries. 
where in this case, $w_{i}=1 / n$,

$\mathrm{n}=$ number of forecasts, and

$\mathrm{X}_{\mathrm{i}}$ represents the individual forecast responses.

\section{Other Data}

The study also uses a number of other specialized data sources. The data on portfolio capital flows were obtained from International Finance group of the World Bank's International Economics Department (IECIF), as was an index of emerging-country "investability" from the International Finance Corporation, as a direct measure of the degree of capital mobility. ${ }^{9}$ As Table 1 indicates, different studies have chosen to explain different variables. Calvo, Leiderman and Reinhart (1993) focused on reserve flows (and changes in the real exchange rate, to address countries that allowed appreciation of their currencies). The advantage is that reserve changes are available on a monthly basis, but the disadvantage is that the overall balance of payments measure includes foreign direct investment, trade, and all other current account transactions, whereas one wants to focus on portfolio investment. Chuhan, Claessens and Mamingi used bond and equity flows from the United States (available from the U.S. Treasury); these data are also available monthly, but pertain only to the behavior of American investors. We believe that the IECIF data, which we have obtained from the World Bank on a quarterly basis, are appropriately broad in their coverage.

An important problem is how to allow for country risk as a determinant of local interest rates. One measure we employ is secondary-market debt prices (made available by Carmen Reinhart of the IMF); the closer are the secondary debt prices to 1.00 , the lower is the

${ }^{9}$ Fernandez Arias (1994) uses the IECIF data. Claessens and Rhee (1994) use the IFC data. The Appendices in Gooptu (1993) discuss the available data, and report on financial restrictions in various countries. 
perceived country risk. Another measure, for those countries that offer dollar-denominated assets (such as the tesobonos in Mexico, or BONEX in Argentina), is the difference between the local dollar rate and the dollar rate on U.S. Treasury bills (or LIBOR). Both measures are endogenous prices; it would be desirable to extend the estimation to see how the perceived country risk is influenced by fundamental determinants such as debt/GDP or debt service ratios and indicators of political instability.

\section{The Gap Between Local Interest Rates and U.S. Interest Rates}

We begin by looking at interest rates in some of the countries. Throughout this study we use short-term interest rates to measure rates of return. For each country we have tried to find the most market-determined interest rate possible. ${ }^{10}$

The first set of charts, Figures 1-5, address the relationship between local interest rates (the dashed lines) and U.S. rates (the solid line), at the 3-month horizon. Chile, Mexico and the Philippines show local interest rates that fell after 1990, but remained substantially higher than the U.S. interest rate throughout the sample. The interesting question is the factors contributing to this differential.

In each figure, the dotted line represents the expected rate of return on local assets in terms of dollars: the domestic interest rate minus expected depreciation as measured by the survey data. For most of the countries, expected depreciation constitutes a large positive share of the interest differential. (The main exception is Taiwan during 1988-1990, the first half of the sample period, when expected depreciation is negative rather than positive. Taiwan available.

${ }^{10}$ Appendix 2 in the working paper version of this paper lists the alternative interest rates 
allowed its currency to appreciate against the U.S. dollar in the late 1980s.)

In the case of Mexico, the expectation-adjusted local interest rate lies relatively neatly between the local and dollar interest rates. ("Relatively" because the survey data are sufficiently variable that some smoothing seems warranted, mentally if not computer-aided.) When the expectation-adjusted rate lies above the dollar interest rate in this way, it indicates a positive expected return differential on local assets. Such a differential is usually interpreted as a risk premium, compensation to investors who view the local assets as riskier than U.S. assets. In the case of Chile and the Philippines, the expectation-adjusted rate hovers in the vicinity of U.S. rates, suggesting that there may be little or no risk premium, or else that the survey data are too noisy to permit meaningful inferences.

For those countries where there exist local interest rates denominated in dollars, which includes Mexico, Argentina, and Chile, a further decomposition of the interest differential is possible. Let $i_{i}^{p}=$ the local peso interest rate, and $i_{U S}{ }^{s}=$ the U.S. interest rate. The total interest differential can be decomposed as follows:

$i_{i}^{p}-i_{U S}^{s}=\Delta \hat{\mathrm{s}}_{\mathrm{t} t+\mathrm{k}}^{\mathrm{e}}+\left(i p-i_{l}^{s}-\Delta \hat{\mathrm{s}}_{\mathrm{l},+\mathrm{k}}{ }^{e}\right)+\left(i_{i}^{s}-i_{U S}^{s}\right)$.

where $\Delta \hat{\mathbf{s}}_{\mathrm{t}, \mathrm{t}+\mathrm{k}}{ }^{\mathrm{e}}$ is the period $\mathrm{t}$ survey-based expected depreciation from time period $\mathrm{t}$ to $\mathrm{t}+\mathrm{k}$ (all variables are annualized);

$\left(i_{i}^{p}-i_{i}^{s}-\Delta \hat{s}_{l, 1+k}{ }^{e}\right)$ is the exchange risk premium, i.e., the compensation for holding currencies that are perceived to be riskier than dollars;

$\left(i_{i}^{s}-i_{U S}^{s}\right)$ is the country premium, i.e., the compensation for holding claims on a country that are perceived to be riskier than claims on the United States, and 
$i_{l}^{s}$ the local dollar-denominated interest rate."

The exchange risk premium and the country premium for Mexico both appear to be positive. Our data indicate, for example, that as of September 1994, the $7.7 \%$ differential between 1-year Mexican CETES and U.S. Treasury bills broke down as follows: expected depreciation of the peso $3.8 \%+$ exchange risk premium $1.8 \%+$ country premium $2.1 \%$.

Figure 6 focuses on 3-month Mexican interest rates from June 1993 to December 1994. It pinpoints the dates of major political events in Mexico during this period, as well as U.S. Federal Reserve decisions to raise the U.S. federal funds interest rate. The uppermost line is the 3-month CETES Mexican peso interest rate. (Some reports suggest that the CETES interest rate became much less representative of Mexican money markets in 1994, as the government withheld supply of the securities to keep the rate low, offering investors large amounts of Tesobonos instead. We have also tried the interest rate on certificates of deposit. The pattern is similar.) Mexican peso interest rates show a clear decline after the American approval of NAFTA in November 1993, and a sharp increase after the assassination of Presidential candidate Luis Colosio. The latter event roughly doubled the premium that Mexico had to pay over the U.S. Treasury bill rate.

In terms of equation (1), do these variations in the Mexican spread take the form of changes in expected depreciation of the peso, the exchange risk premium, or the country premium? From the graph, the answer appears to be the currency factors. There is relatively little variation in the country premium, the difference between the Tesobono rate and the U.S.

11 One can readily undertake an analogous decomposition for the differential in real interest rates. The expected nominal depreciation term is then replaced by expected real depreciation. This line of thought is pursued in Frankel (1993). 
interest rate. But expected depreciation of the peso rises sharply after the Chiapas uprising in January 1994, and falls sharply in September 1994 with the peaceful reaction to the Zedillo election. The exchange risk premium, measured as the gap between the expectation-adjusted CD interest rate and the Tesobono interest rate, also declines with the NAFTA vote and Zedillo election.

\section{The Relationship Between Local Expected Returns and U.S. Rates}

We begin the econometrics with regressions of local interest rates, adjusted for expected depreciation, against the U.S. 3-month Treasury bill interest rate:

$i_{i}^{p}-\Delta \hat{s}_{i,++k}{ }^{e}=\alpha+B i_{U S}{ }^{s}+\epsilon$.

The null hypothesis is $\beta=1$, which would signify perfect capital mobility as well as perfect substitutability between peso and dollar assets. ${ }^{12}$

We started with a sample consisting of Argentina, Chile, Mexico, Philippines, Korea, Singapore, and Taiwan. The sample period is 1987 - 1994. The coefficient estimate for B was absurdly high, reflecting interest rates in Argentina that were in excess of one million per cent per annum during the hyperinflation of 1989-1990. Accordingly we dropped Argentina from the sample. The result, reported in Table 2, is a coefficient estimate of 1.4, which, statistically, is significantly greater than zero and not significantly different from one. This result constitutes a failure to reject the null hypothesis of perfect capital mobility and perfect substitutability.

12 Studies of the effect of U.S. (or Japanese) interest rates on the interest rates of Pacific Rim countries include Chinn and Frankel (1994a, 1995) and Glick and Moreno (1994). 
We found it noteworthy that the point estimate was greater than unity. When Mexico is excluded along with Argentina (because it was also a high-inflation country in 1987-1988, though far from hyperinflation), the coefficient lies even further above 1.0, and the difference becomes statistically significant. One possible explanation is that the national interest rates include some risk of default or other country risk, and that this risk is correlated with world interest rates. We attempted to correct for the country risk premium by including the secondary-market price of debt on the right-hand side of the equation. The theory is that a higher price for secondary debt indicates lower country risk, and thus requires a lower local interest rate.

Secondary market prices are not available for Korea, Singapore and Taiwan, essentially because the debt would trade at par. When these three countries are excluded from the analysis, the secondary debt price has the expected negative effect on local interest rates (with borderline statistical significance). But the coefficient on the U.S. interest rate remains very large.

We tried setting the secondary debt price for Korea and Taiwan equal to 100 , and including these countries in the test. With Argentina included, the coefficient on the secondary debt price appears to be negative and clearly significant statistically; but the coefficient on the U.S. interest rate is again absurdly high. When Mexico before June 1989 and Argentina are both eliminated from the sample, the coefficient on the U.S. interest rate becomes a reasonable 1.47 , with a standard error that as before allows a clear rejection of zero effect and does not reject 1.00 . In other words it again supports the null hypothesis of perfect substitutability. However the coefficient on the debt price, while highly significant statistically, puzzlingly 
becomes positive. When Mexico and Argentina are removed from the sample entirely, both coefficients become even higher and more significantly greater than zero; indeed the coefficient on the U.S. interest rate becomes significantly greater than 1.0 .

We allowed for fixed effects for each of the countries. Chile, the Philippines, and Taiwan each show that they are able to pay rates of return significantly less than the other countries. The results for the coefficient on the U.S. interest rate and the debt price are qualitatively unchanged.

\section{An Analysis of Mexican Interest Rates Leading Up to December 1994}

As already noted, for a few countries like Mexico, there exists an alternative way of adjusting for country risk, in place of the secondary debt price. The tesobono interest rate in Mexico, shown in Figure 6, is denominated in dollars (though payable in pesos). Thus the gap between it and U.S. interest rates reflects only the country premium. We have tested the determinants of each of the components of the Mexican peso interest rate, both external determinants, as measured by the U.S. Treasury bill rate, and internal determinants, as measured by a dummy variable equal to +1 in the aftermath of the NAFTA vote and Zedillo election, equal to -1 in the aftermath of the Chiapas uprising, the two assassinations, and the December 1994 peso crisis. [The regressions are reported in Table 2b.] Both the event dummy and the interest rate appear to have highly significant effects on the tesobono, the Mexican dollar-denominated interest rate (column 6). The expected effect of U.S. interest rates on the other Mexican interest rates, however, does not show up during this period.

The effect of the event dummy on the CETES interest rate (the sum of all the 
components, in column 1) is high in economic magnitude and in statistical significance: each of the political events raises or lowers the peso interest rate by an estimated 2 per cent ( 200 basis points). The estimated effect is divided roughly equally between the country premium

( 80 basis points, in column 4$)$ and the currency premium (115 basis points in column 7$)$. It also has a large estimated effect on the exchange risk premium (column 3 ), though it is statistically insignificant, probably owing to the small number of monthly observations for which the survey data are available, and perhaps measurement error in the survey data as well.

The lower half of the table corrects for high first order serial correlation by running the regressions on first differences. (In other words, the dummy variable is set up so that political events have a temporary effect on the change in interest rates, rather than -- what is equivalent -- a permanent effect on the level.) The effect of U.S. interest rates on Mexican interest rates loses all significance in these results, but the significance of the event dummy remains. Each adverse political event raises the country premium, and therefore the tesobono interest rate, by an estimated 47 basis points (highly significant). The estimated effect on the currency premium is a reduced 27 basis points (not significant), for a combined effect on the peso interest rate of 73 basis points (significant).

\section{The Portfolio Capital Flow Equation}

The next step is to introduce the quarterly World Bank data on portfolio capital flows. We regress the inflows against the U.S. interest rate, the local interest rate, and expected depreciation. Sometimes we impose the constraints that the coefficient on the local interest rate be equal in magnitude and opposite in sign to the coefficients on expected depreciation and the 
U.S. interest rate:

$$
P C I=A+B\left(i_{i}^{p}-i_{U S}{ }^{s}-\Delta \hat{s}_{t, i+k}^{e}\right)+u
$$

The inflows are first expressed in level form. We also include the log of the GDP of the host country (expressed in dollars) as an explanatory variable. Fernandez-Arias (1994) and Fry (1993, 1994) deflated nominal capital flows by nominal GDP; adding GDP on the right-hand side seems a less restrictive way to allow for scale effects.

In Table $3 \mathrm{a}$, the coefficient on the U.S. interest rate has the expected negative effect on capital inflows, is of a very large magnitude, and is statistically significant. The coefficients on the domestic interest rate and expected depreciation have the hypothesized signs, positive and negative, respectively, but are not significant. The lack of significance holds regardless whether the coefficient magnitudes are constrained to be equal. Indeed when the magnitude of the coefficient on the U.S. interest rate is constrained to be the same as the other two, it loses its significance. It is quite possible that the survey data measure the forecasts of market participants with error. An errors-in-variables problem would bias downward the coefficient on expectations, or on any rate-of-return variable that includes expectations.

When we allow for a dummy variable for each country, these country effects are statistically significant; but the results for the rates of return are qualitatively unchanged, in the respect that the U.S. effect is still statistically significant and the local effect is still not. Similarly, the results are qualitatively unchanged in Table 3b, where Argentina before 1990 Q2 and Mexico before 1989 Q2 are excluded from the sample due to their high inflation rates.

The results are improved when we try expressing the dependent variable as the log of $P C I(+1$, to cope with zero-observations), reported in Table $3 \mathrm{c}$. The negative coefficient on 
expected depreciation becomes statistically significant, though the positive coefficient on the domestic interest rate does not. The highly significant coefficient on the U.S. interest rate shows a point estimate of .32 when the log of GDP is the only additional factor, and a point estimate of .65 when country effects are added as well. These estimates are semi-elasticities, revealing the percentage response in portfolio capital inflows resulting from a decline in U.S. interest rates (adjusted for expected depreciation) of 1 per cent.

Next we add the secondary debt price as another variable to help explain capital inflows in equation (3), under the theory that it will help adjust the local interest rate for country risk. The debt price in Table $3 \mathrm{~b}$ turns out to have the hypothesized positive effect on capital inflows, though it is not significant. The other estimates are as before: correctly signed for the U.S. interest rate, local interest rate, and expected depreciation, but only significant for the first of these.

We also try the equation in inverted form:

$$
\left(i_{l}^{p}-i_{U S}{ }^{s}-\Delta \hat{s}_{t,++k}{ }^{e}\right)=-A / B+(1 / B) P C I+v .
$$

This specification has two major advantages. First, it allows a new test of the null hypothesis of perfect capital mobility and substitutability, $1 / B=0$. (It would not be feasible in the preceding equation to test $B=\infty$.) Second, the inverted specification also has the advantage that, as in equation (2), any measurement error in the survey data goes into the regression error and need not bias the regression estimate. We must acknowledge that equation (3) and equation (4) cannot both be correctly specified. If one set of regressions is right, then the other is wrong.

Estimates for the inverted specification are reported in Table 4. The country effects are 
not statistically significant, with the exception of the coefficient on the dummy for Argentina. The coefficient on $P C I$ is not statistically significant. Nor is the coefficient on the secondary debt price (whose sign is negative, as hypothesized), nor most of the country effects. An $F$ test fails to reject the hypothesis that all coefficients are zero. In other words, we fail to reject the hypothesis that capital flows are strong enough to set the international differential in expected rates of return to zero. This constitutes a failure to reject perfect capital mobility, perfect substitutability, and a zero scope for sterilization of inflows. The results are again qualitatively unchanged when Argentina pre-1990Q2 and Mexico pre-1989Q2 are excluded from the sample, or when the secondary debt price is included as a regressor.

To return to a question posed at the outset, if capital mobility is indeed sufficiently high to equate expected returns internationally, then why have local interest rates failed to converge to U.S. levels? Evidently the answer is expectations of depreciation or devaluation of the local currencies against the dollar. This conclusion suggests that if attempts at sterilized intervention create difficulties, it may be because they create expectations of future monetization, inflation, and depreciation, rather than by creating a risk premium. But there is as yet little reason to think that the expectations of depreciation are greater than under the alternative responses to a capital inflow, nonsterilized intervention or appreciation.

These results are highly preliminary. We would like to explore the sensitivity of the results, for example, with respect to the interest rate measures used and with respect to correlation across countries. We would like to include other direct measures of capital controls on the right-hand side of equation (3), perhaps multiplicatively with the expected return differential. (One measure we have tried is the IFC investability index, but it did not perform 
particularly well in this context.) We would like to include local dollar interest rates for those countries where they are available (Mexico, Chile, and Argentina) along with peso interest rates in equation (3). We would like to include country variables such as debt/GDP and debt-service ratios, inflation rates, and indicators of political instability, perhaps allowing for the secondary market price of debt to be determined endogenously.

Our statistical failure to reject perfect capital mobility in Table 4 is what we have. The finding is consistent with the strong relationship in Table 2 between U.S. interest rates and domestic interest rates adjusted for expected depreciation. Traditionally in econometrics, failures to find statistically significant results have been considered discouraging. Bad data or insufficient data could produce the lack of statistical significance as easily as could the virtue of the null hypothesis. In modern finance econometrics the failure to reject an important null hypothesis such as market efficiency is often considered reason for pride. We, however, incline to the traditional interpretation, that failure to reject the null hypothesis does not allow one to assert that the null hypothesis is necessarily true.

\section{The Offset Equation}

The next step is to introduce a different measure of credit market conditions into equation (3), in place of the domestic interest rate, namely the domestic money supply. The aim is to estimate the so-called offset coefficient: the negative effect of domestic credit expansion on the capital account. We do so by introducing a money market equilibrium condition.

$$
m=p+\phi y-\lambda i_{i}^{p}
$$


where $m=$ is the log of the domestic money supply, which is in turn the sum of reserves and domestic credit;

$p=$ the $\log$ of the price level; and

$y=$ the $\log$ of real GDP.

We proceed to solve for the interest rate and substitute out for it in the capital flow equation:

$$
P C I=A+B\left[(-1 / \lambda)(m-p)+(\phi / \lambda) y-i_{U s}^{s}-\Delta \hat{s}_{l, l+k}^{e}\right]+u .
$$

One can also decompose the money supply into domestic credit and reserves, but tests on such data are not reported here. Instead, we will continue to aggregate them together. ${ }^{13}$

The null hypothesis of full integration into world financial markets now becomes the proposition that the offset to domestic credit is complete and instantaneous. This is the hypothesis that the coefficient $B / \lambda$ is so high that an increase in domestic credit equal to one per cent of the money supply produces a capital outflow of the same size. (For simplicity, we impose the constraint $\phi=1$, so that we can combine the real income and price level terms into a single nominal GDP variable, as we have been doing on the righthand side of our equations all along. All quantities are measured in dollars.)

OLS estimates of equation (6) are reported in Table 5. First, in keeping with our approach thus far, we use the quarterly flow of portfolio capital as the dependent variable. The results are surprisingly good, for this line of work ${ }^{14}$. The coefficients on the monetary base and nominal GDP are both highly significant statistically, and are opposite in sign and

13 The $\log$ of the money supply can be approximated as a weighted average of the logs of reserves and domestic credit:

$m=(D) d c+(I-D)$ res. The form of the offset equation that focuses explicitly on domestic credit is: $P C I=A+B\left[(-1 / \lambda)((D) d c+(1-D)\right.$ res $\left.-p)+(\phi / \lambda) y-i_{u s}{ }^{s}-\Delta \hat{s}_{t, 1+k}{ }^{e}\right]+u$.

14 See, e.g., Fry $(1993,1994)$ for six East Asian countries, on a time sample ending in 1991. 
approximately equal in magnitude, as they should be. The point estimate suggests that every one per cent expansion in the monetary base, in excess of nominal GDP growth, causes a loss of capital flows in the same quarter equal to about $\$ 3$ million (or $\$ 12$ million at an annual rate). For Mexico, one per cent of the monetary base, on average during the sample period, was $\$ 89$ million. (Mexico is close to the average of the five countries in this regard.) Thus the estimated offset within the quarter was roughly 3.4 per cent $(=\$ 3 / \$ 89)$. Such estimates should be taken as only illustrative.

An alternative specification would be to treat the cumulated stock of capital inflows as the dependent variable, rather than the flow. This is the portfolio-balance specification, which is relevant if the factor preventing perfect arbitrage is thought to be imperfect substitutability between dollar assets and peso assets, rather than remaining capital controls or other frictions in the international capital markets. The data seem to prefer this specification: the fit is better, whether measured by the level of significance of the key coefficients, the F-statistic, $R^{2}$, or adjusted $R^{2}$. Now the point estimate is that for every one per cent expansion of the monetary base in excess of nominal GDP, the country loses about $\$ 25.3$ million in portfolio capital in that quarter. For Mexico, this is an offset of roughly 28 per cent in the quarter $(=\$ 25.3 / \$ 89)$.

The coefficients on the U.S. interest rate and expected depreciation of the domestic currency are also of the correct sign. The former is statistically significant, but the latter only marginally so. We have allowed dummy variables to pick up country effects. Chile and Argentina stand out as able to attract more capital than the others, holding the macroeconomic determinants constant. The Philippines stands out in the opposite direction, but this country effect is not statistically significant. 
In practice, researchers have allowed lags in the process whereby an expansion of domestic credit leaks out through the capital account. The question then becomes how much of the expansion is offset in the first quarter, versus later. We allowed for as many as four quarters of lags on the monetary base. The sum of the coefficients on lagged and contemporaneous money were always about the same as the coefficient on contemporaneous money reported in Table 5. Because the overall offset estimates are not much affected, we do not report these results separately.

We repeat the tests with the broad money supply in place of the monetary base, in other words including the liabilities of the banking system rather than just of the central bank. The results, reported in columns (2) and (4) of Table 5, are strikingly similar to the results for monetary base. Again, all coefficients are of the correct sign, and those on money, nominal GDP and the U.S. interest rate are highly significant statistically. The main difference is that the estimated offset to a one per cent increase in broad money is 30 per cent smaller than the estimated offset to a one per cent increase in narrow money. ${ }^{15}$ The other difference is that Argentina and Mexico join the Philippines in showing significant negative country effects.

Three important extensions remain for future work. First, it is not legitimate to constrain all the countries in our sample to have the same offset coefficient. Policy responses varied across countries, and for that matter across time as well. Chile, for example, reinstituted some controls on capital inflows, in the form of deposit requirements. Our plan is to introduce into the offset equation a direct measure of capital controls, equal to 1 for a financially open

15 A one per cent increase in broad money is $\$ 809$ million on average for Mexico. So the effect on the stock of capital of $\$ 17.55$ million represents an offset, in these terms, of only 2.2 per cent $[=\$ 17.55 / \$ 809]$. 
country and 0 for a closed one. If the IFC investability index does not seem to capture what we want, then we may use a dummy variable based on the IMF's Exchange Arrangements and Exchange Restrictions, as used by Grilli and Milesi-Ferretti (1995). Whatever the measure, it would be interacted in equation (6) with all righthand-side variables. The hope would be that this variable would capture the cross-country (and cross-time) variation in $B$, so that the coefficients could then be interpreted as representing offset in the case of the financially open countries. Second, we have not yet estimated an offset equation taking proper simultaneous account of the sterilization equation, representing central banks' tendency to vary domestic credit in response to balance of payments inflows. The simultaneous estimation of offset and sterilization, which would of course require suitable instrumental variables, is our next priority for this project. Third, it might be worth distinguishing in the econometrics between periods of net capital inflow and periods of net capital outflow.

Our results to date, however, may be described as a finding that the offset to domestic credit is highly significant statistically, though appearing to fall far short of instantaneous and complete offset.

\section{Conclusions}

Our results suggest a number of conclusions. First, U.S. interest rates are a very major determinant of financial conditions in the emerging-market countries. Whether one looks at the effect on portfolio capital flows or the effect on local interest rates, it effect is high and significant. Indeed, changes in U.S. interest rates seem to have an effect on local interest rates that is more than one-for-one. This confirms the finding of Calvo and others that low world 
interest rates were a major factor in the new capital inflows of 1990-1993. Vulnerability to increases in U.S. interest rates such as took place in 1994 could have been (and was) predicted.

Second, consistent with findings of close links to world financial markets, we find a substantial offset to monetary policy: the estimate suggests for Mexico that a monetary expansion is followed by a capital outflow within the same quarter equal to 0.28 per cent of the increase in the monetary base. The offset is not complete, however.

Third, we find evidence against the view that the existence of country risk or remaining capital controls is the major reason why interest rates in recipient countries remained above U.S. interest rates in 1990-94. To be sure, country risk, measured for example by the discount in the secondary debt market, is a significant determinant of country interest rates. But a decomposition of interest differentials into country premium and currency premium shows that the latter is generally larger. When countries have difficulty sterilizing inflows, in the sense that the issue of domestic bonds drives up the local interest rate, the interest differential may be interpretable in large part as compensation for expected future depreciation.

Fourth, a more in-depth analysis of weekly Mexican interest rates during the period June 1993 - December 1994 shows significant adverse effects coming both from Federal Reserve decisions to raise U.S. interest rates and from political events in Mexico. The effects show up both in Mexican dollar-denominated interest rates (tesobonos) and peso-denominated rates (CETES), indicating that the currency premium and country premium were equally important.

It is useful to be able to look at local dollar-denominated interest rates when they are available -- as they are for Mexico, Argentina, and Chile -- in order to measure the country premium, i.e., the spread over U.S. dollar interest rates. Nevertheless it can be dangerous to 
look only at dollar interest rates, as opposed to local-currency interest rates. Econometricians who do so in studies of sterilization and offset are missing the currency premium, which, as noted, is often larger than the country premium. For policy-makers to focus too heavily on local dollar-denominated interest rates is even more dangerous. After the capital flows to Mexico began to reverse in February 1994, the Mexican response was sterilized intervention of the reserve outflows. Anyone who judged the success of this response by looking at tesobono interest rates underestimated the magnitude of the problem. The increase in peso interest rates was much greater than the increase in dollar interest rates in Mexico, signifying a large increase in the currency premium and, as we now know, a lack of sustainability in the exchange rate policy. 


\section{References}

Calvo, Guillermo, 1991, "The Perils of Sterilization," IMF Staff Papers 38, no. 4, December, 921-926.

Calvo, Guillermo, Leo Leiderman and Carmen Reinhart, 1993, "Capital Inflows and Real Exchange Rate Appreciation in Latin America: The Role of External Factors," IMF Staff Papers 40, no.1, March, pp.108-150.

Calvo, Guillermo, Leo Leiderman and Carmen Reinhart, 1994, "The Capital Inflows Problem: Concepts and Issues," Contemporary Economic Policy XII, July, 54-66.

Calvo, Guillermo, Leo Leiderman and Carmen Reinhart, 1994b, "Capital Inflows to Latin America: The 1970s and the 1990s," forthcoming in Edmar Bacha, ed., Development. Trade and the Environment, London: MacMillan Press.

Calvo, Guillermo, Leo Leiderman and Carmen Reinhart, 1995, "Inflows of Capital to Developing Countries in the 1990s: Causes and Effects," Economic Perspectives.

Calvo, Sara, and Carmen Reinhart, 1994, "Capital Flows to Latin America: Have the Small Countries Been Left Out?" World Bank and International Monetary Fund, December.

Chinn, Menzie, and Jeffrey Frankel, 1994a, "Financial Links Around the Pacific Rim: 19821992," in Exchange Rate Policy and Interdependence: Perspectives from the Pacific Basin, edited by R. Glick and M. Hutchison, Cambridge University Press, Cambridge UK and New York, 17-47.

Chinn, Menzie, and Jeffrey Frankel, 1994b, "Patterns in Exchange Rate Forecasts for 25 Currencies," Journal of Money, Credit and Banking, November.

Chinn, Menzie, and Jeffrey Frankel, 1995, "Who Drives Real Interest Rates in the Pacific Rim: The United States or Japan?," Working Paper No. 284, University of California, Santa Cruz. In Journal of International Money and Finance, forthcoming December.

Chuhan, Punam, Stijn Claessens and Nlandu Mamingi, 1994, "Equity and Bond Flows to Latin America and Asia: The Role of Global and Country Factors," The World Bank. Revised, October 1994.

Claessens, Stijn, and Moon-Whoa Rhee, 1994, "The Effect of Equity Barriers on Foreign Investment in Developing Countries," in The Internationalization of Equity Markets, edited by J. Frankel, University of Chicago Press, Chicago.

Cline, William, "Capital Markets in the 1990s," 1995, Chapter 8 in International Debt 
Reexamined, Institute for International Economics, Washington, DC.

Cumby, Robert, and Maurice Obstfeld, 1983, "Capital Mobility and the Scope for Sterilization: Mexico in the 1970s," in Financial Policies and the World Capital Market: The Problem of Latin American Countries, Pedro Aspe Armella, Rudiger Dornbusch and Maurice Obstfeld, eds., University of Chicago Press: Chicago, 245-269.

Dooley, Michael, Eduardo Fernandez-Arias, and Kenneth Kletzer, 1994, "Recent Private Capital Inflows to Developing Countries: Is the Debt Crisis History?" NBER Working Paper No. 4792, July.

Edwards, Sebastian, 1986, "The Pricing of Bonds and Bank Loans in International Markets: An Empirical Analysis of Developing Countries' Foreign Borrowing," European Economic Review 30, 3, 565-89.

Edwards, Sebastian, 1991, "Politica Monetaria y Cambiaria en Colombia," paper prepared for the Banco de la Republica, Bogota, Colombia, December.

Fernandez-Arias, Eduardo, 1994, "The New Wave of Private Capital Inflows: Push or Pull?" Policy Research Working Paper 1312, Debt and International Finance Division, International Economics Department, The World Bank, June.

Fernandez-Arias, Eduardo, and Peter Montiel, 1995, "The Surge in Capital Inflows to Developing Countries: An Overview," World Bank, January.

Frankel, Jeffrey, "Quantifying International Capital Mobility in the 1980's." Chapter 2 in J.Frankel, On Exchange Rates, M.I.T. Press: Cambridge, MA, 1993.

Frankel, Jeffrey, "Sterilization of Money Inflows: Difficult (Calvo) or Easy (Reisen)?" Latinamerican Macroeconomic Network, Cartagena, Colombia, July 29-30, 1993; CIDER Working Paper 93-024, U.C.Berkeley; published (in Spanish), in Afluencia de Capitales y Establizacion en America Latina, edited by Roberto Steiner, Fedesarrollo, Bogota, 1994: 241267. IMF Working Paper No. 94/159, Dec. 1994.

Frankel, Jeffrey, and Menzie Chinn, 1993, "Exchange Rate Expectations and the Risk Premium: Tests for a Cross-Section of 17 Currencies," Review of International Economics 1, no.2 (June), 136-144.

Froot, Kenneth, and Jeffrey Frankel, 1989, "Forward Discount Bias: Is it an Exchange Risk Premium?", Quarterly Journal of Economics 104, no.1 (February 1989), 139-161.

Fry, Maxwell, 1993, "Financial Opening and Monetary Control in Pacific Basin Developing Countries," in Helmut Reisen and Bernhard Fischer (eds.) Financial Opening: Policy Issues and Experiences in Developing Countries, (Paris: OECD): 143-165. 
Fry, Maxwell, 1994, Money, Interest, and Banking in Economic Development, Johns Hopkins University Press, Baltimore, 2nd edition [1st ed. 1988].

Glick, Reuven, and Ramon Moreno, 1994, "Capital Flows and Monetary Policy in East Asia," Pacific Basin Working Paper No. PB94-08, Federal Reserve Bank of San Francisco, Nov.

Goldstein, Morris, 1995, "Coping with Too Much of a Good Thing: Policy Responses for Large Capital Inflows to Developing Countries," World Bank, March.

Gooptu, Sudarshan, 1993, "Portfolio Investment Flows to Emerging Markets," Chapter 3 in Portfolio Investment in Developing Countries, edited by Stijn Claessens and Sudarshan Gooptu, World Bank Discussion Paper No. 228, The World Bank.

Grilli, Vittorio, 1995, "Economic Effects and Structural Determinants of Capital Controls," Research Department, International Monetary Fund, January.

Kamas, Linda, 1985, "External Disturbances and the Independence of Monetary Policy Under the Crawling Peg in Colombia," Journal of International Economics 19.

Kamas, Linda, 1986, "The Balance of Payments Offset to Monetary Policy: Monetarist, Portfolio-Balance, and Keynesian Estimates for Mexico and Venezuela," Journal of Money, Credit, and Banking, 18.

Kouri, Pentti, and Michael Porter, 1974, "International Capital Flows and Portfolio Equilibrium," Journal of Political Economy 82, May, 443-467.

Rennhack, Robert, and Guillermo Mondino, 1988, "Capital Mobility and Monetary Policy in Colombia," IMF Working Paper 88/77, August.

Rodriguez, Carlos, 1994, "Interest Rates in Latin America," Centro de Estudios Macroeconomicos de Argentina No. 98, Buenos Aires, April.

Schadler, Susan, Maria Carkovic, Adam Bennett, and Robert Kahn, 1993, "Recent Experiences with Surges in Capital Inflows," Occasional Paper 108, International Monetary Fund.

Williamson, John, 1994, "The Management of Capital Inflows," Institute for International Economics, December. 
Figure 1

\section{Mexico}

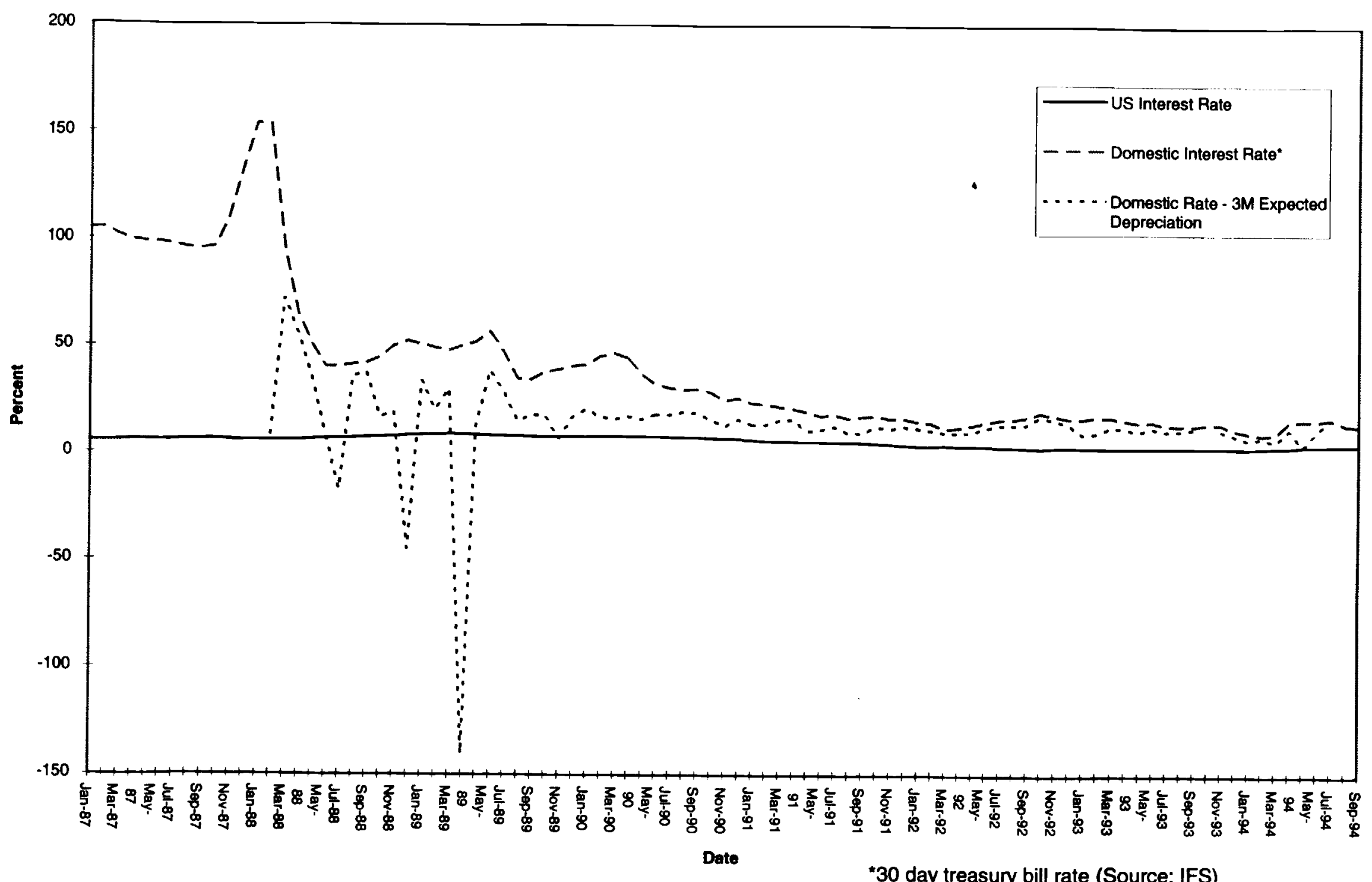


FIgure 2

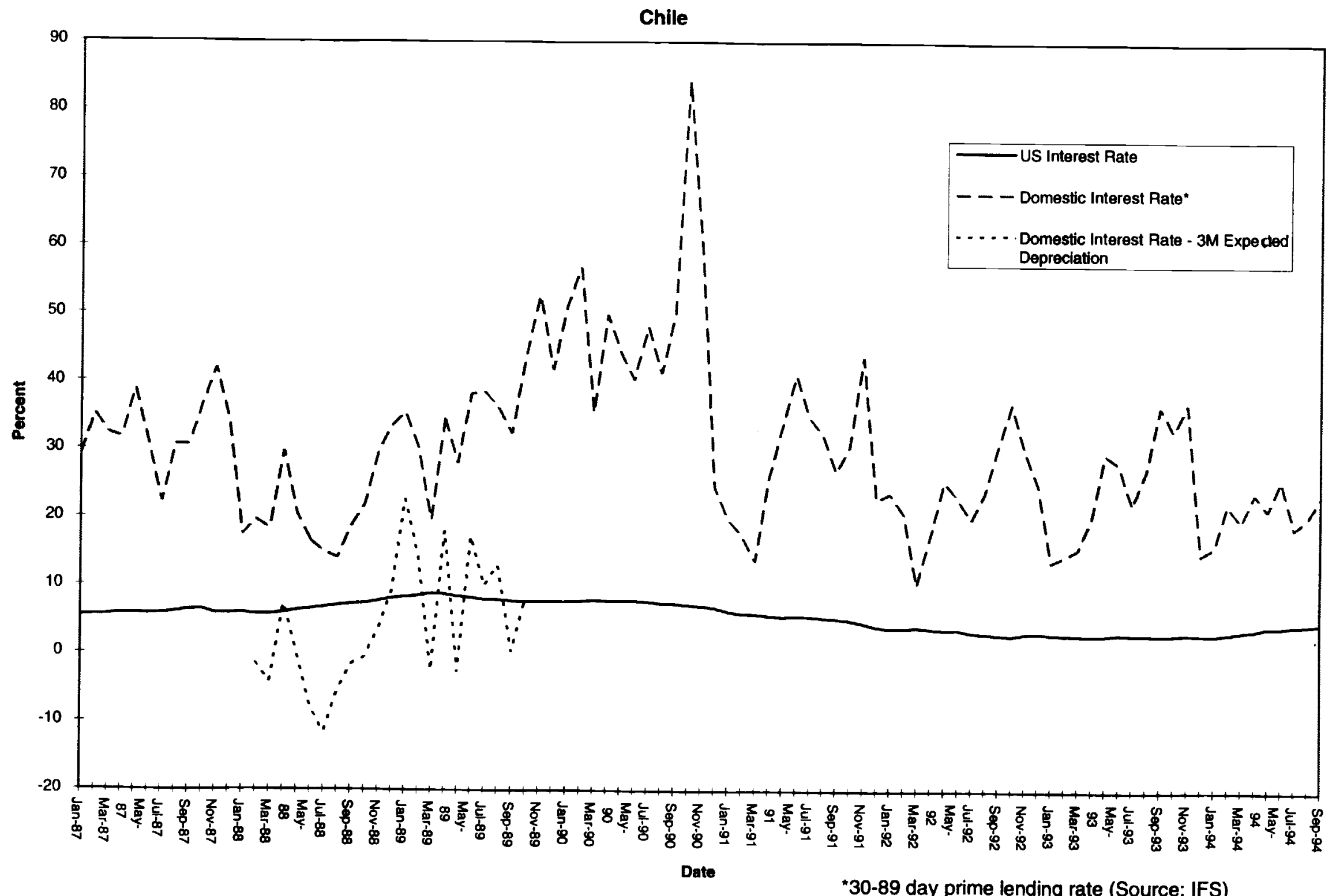


Figure 3

\section{Philippines}

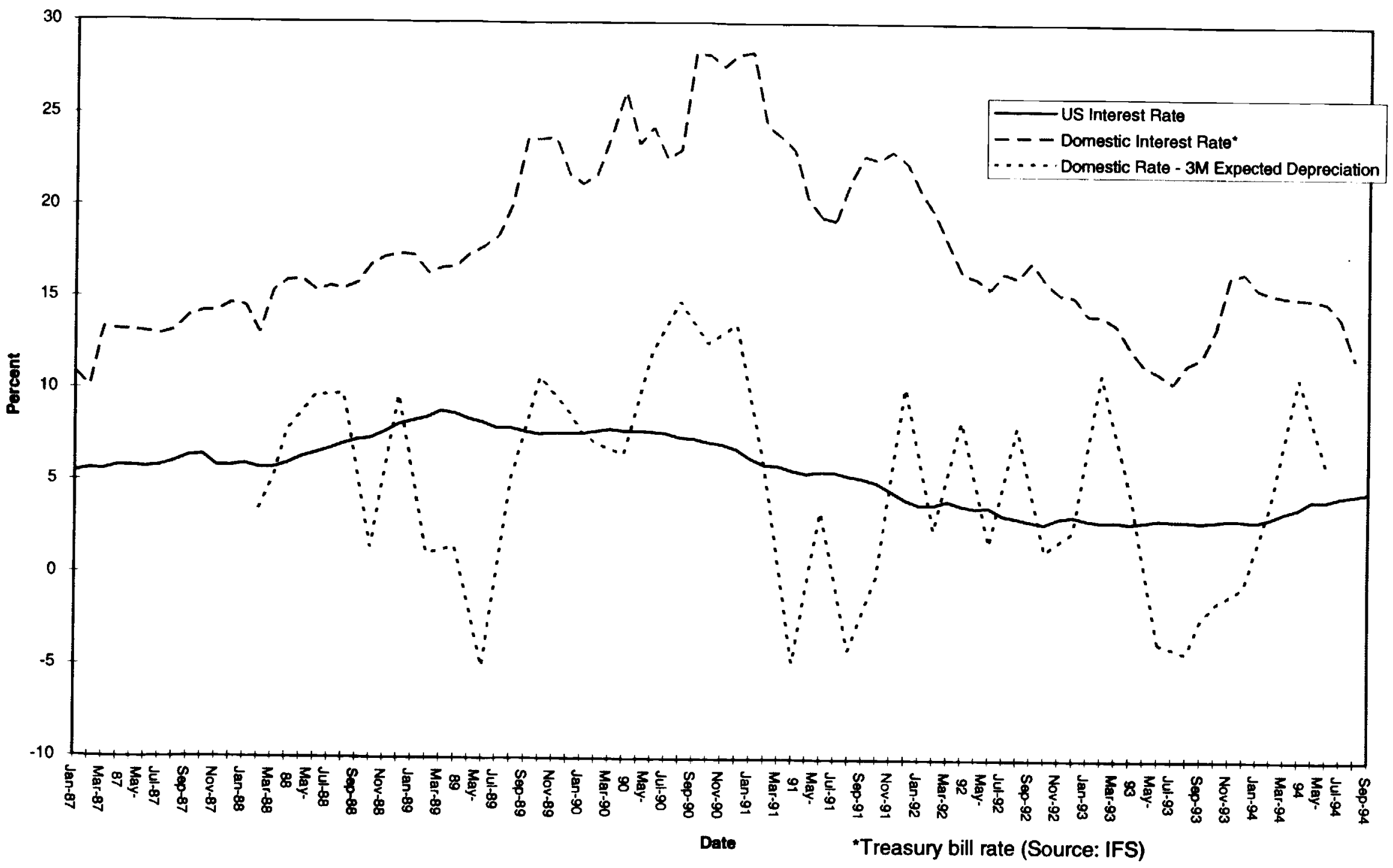


Figure 4

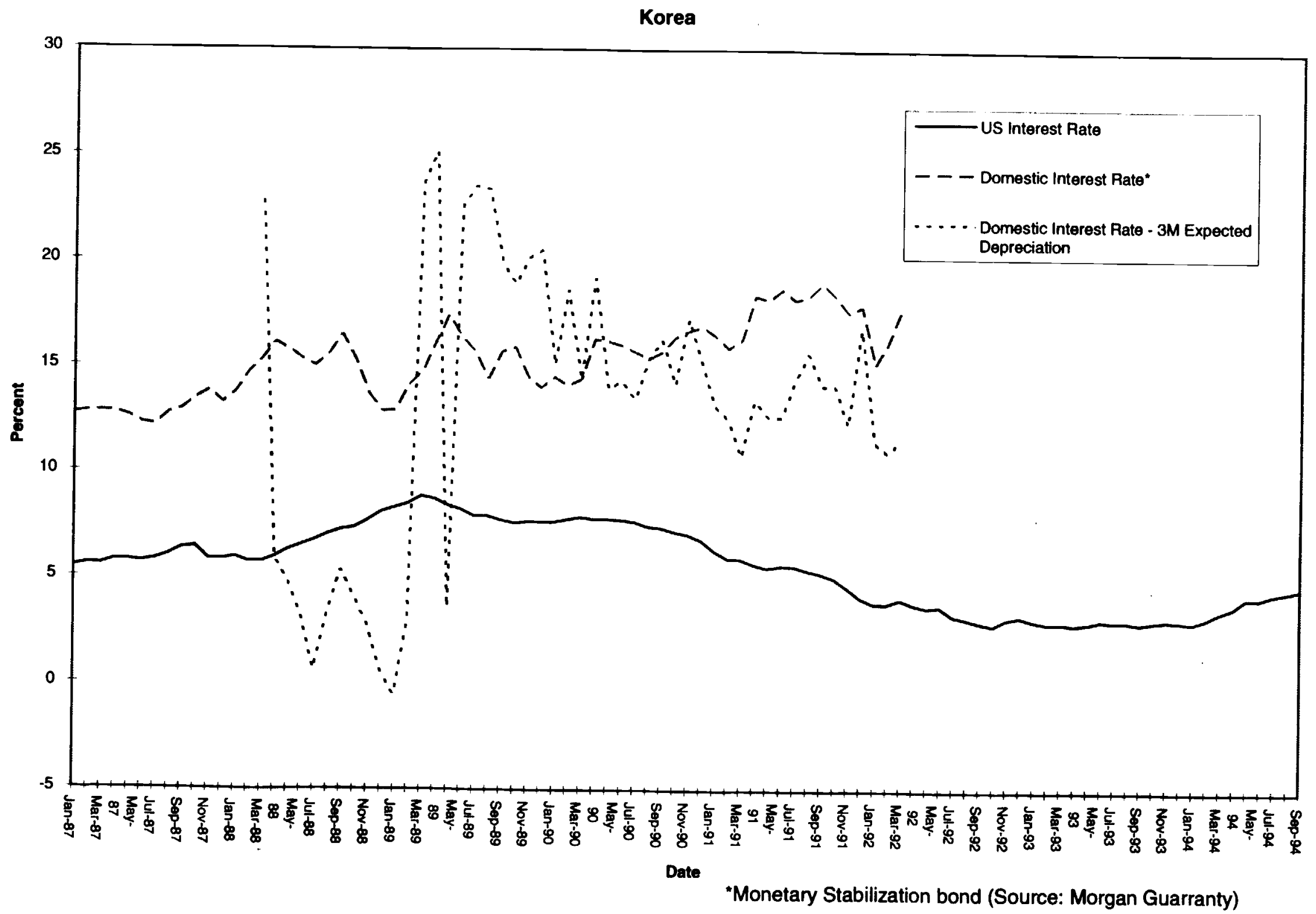


Figure 5

\section{Taiwan}

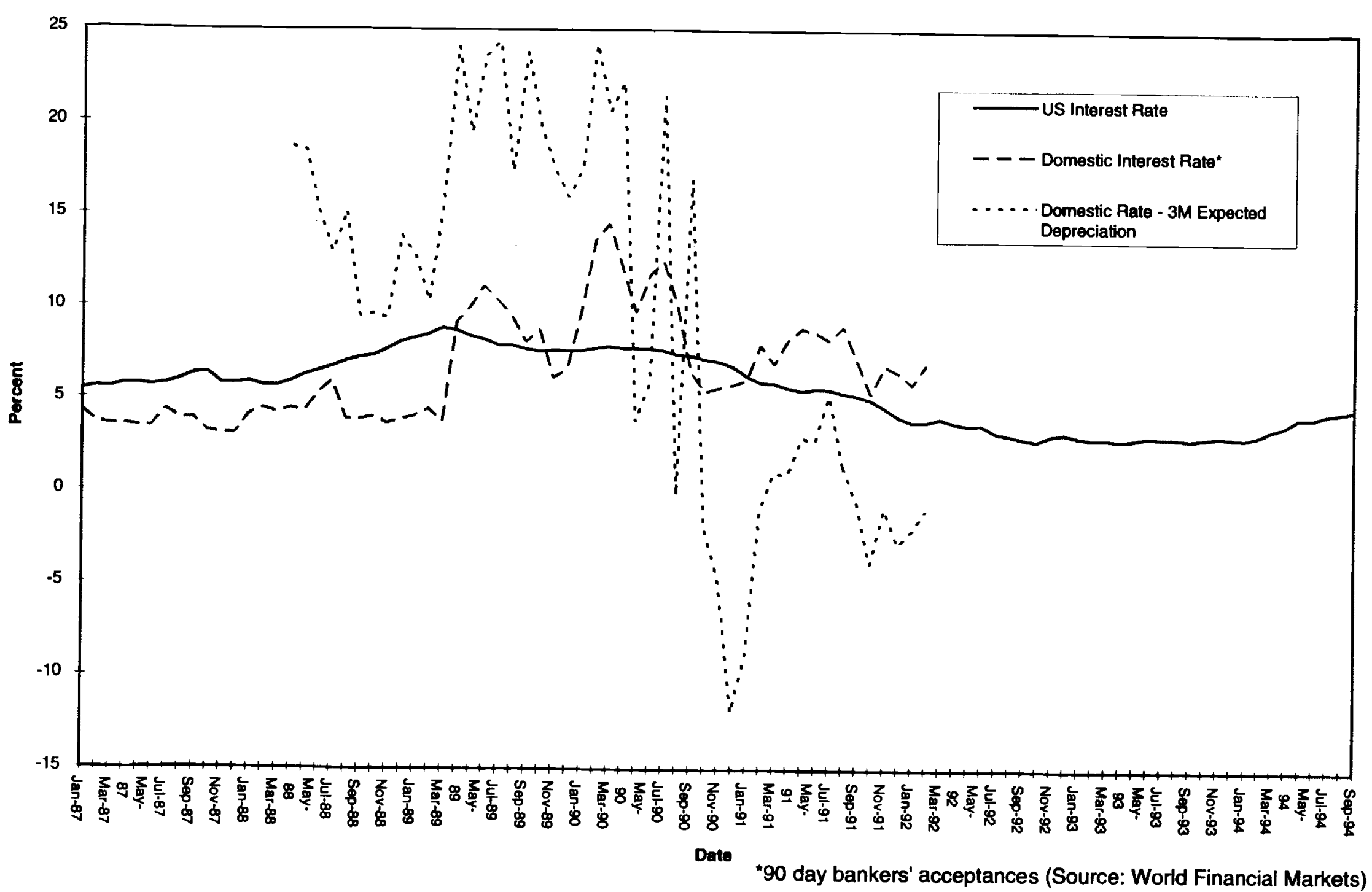




\section{Mexican Interest Rates}

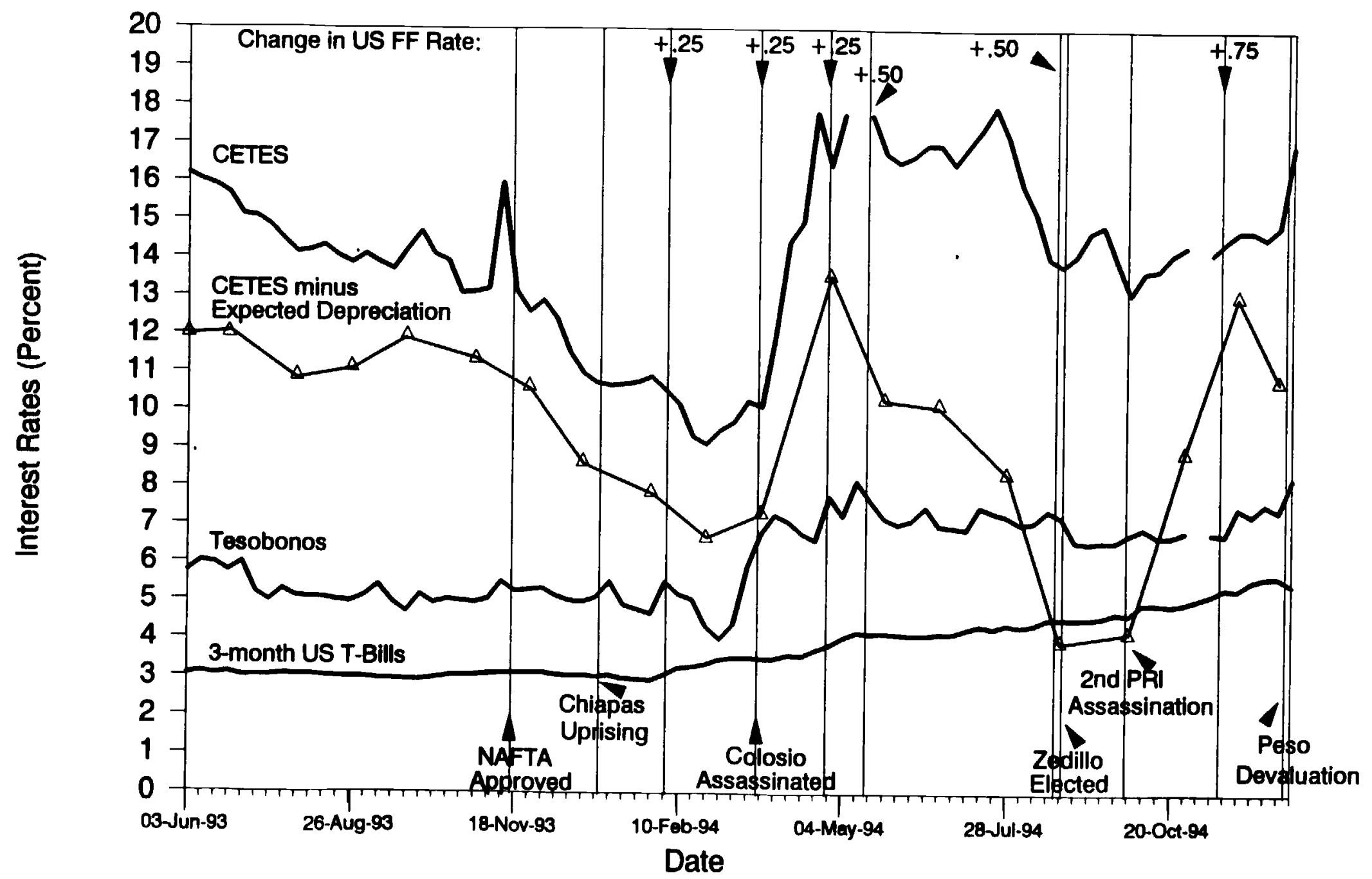

Interest rates are weekly from June 3, 1993 to December 21, 1994

Expected depreciation is measured by Currency Forecasters' Digest monthly surveydata smoothed over three months.
Last survey date is December 15,1994 . 


\begin{tabular}{|c|c|c|c|c|c|}
\hline & & Economelnic Studies of Recen & Pontolio Capital From & & \\
\hline \multirow[t]{3}{*}{ STUDY } & Oruhno, Oresucm. & Cano, Leiderman & Schndlex & Rernacede-Ario & Dooley, Femander-Arim \\
\hline & and Maming & and Reiaburt & at ins & 198 & and Retuer \\
\hline & & MAF SP $19 \mathrm{~B}$ & & & NBER IMA \\
\hline \multirow[t]{2}{*}{ SAMPLE } & 9 Latin Amerian A & 10 Latin American & 6 countrites & 23 covouritas & 18 covatines \\
\hline & 9 Arian countries & countries & & & \\
\hline \multirow[t]{3}{*}{ period } & 190000 & $19:-91.12$ & $\sin x+18 x-n$ & thasn & 1 15x-152 \\
\hline & (monthly) & (moninty) & (quarterty) & (quanterty) & (anauni) \\
\hline & panel & cowntry by country & couatry by country & panel & penel \\
\hline DEPENDENT & grow bond nows & resene nom & NFA chenges & toul port. fom/ & $P$ acoudary debt \\
\hline \multirow[t]{2}{*}{ VARLABLE } & A net equiry nom & (+ Real Ex Rait changes) & $(+i \log )$ & I(GNPXONIn] & \\
\hline & $\begin{array}{l}\text { (ez no subiracen of } \Delta \mathrm{CB} \\
\text { holding of foreip boods) }\end{array}$ & sisulhereounty & 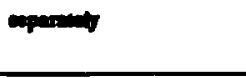 & & \\
\hline \multirow[t]{6}{*}{ cowrex } & US Trensury & IFS & IFs & IECOI (BRD) tant $=$ & Salomon Brothers \\
\hline & (Comeried for Brady & & & & \\
\hline & issues by dummies.) & & & & \\
\hline & Heusmano $T(81)$ teat $=>$ & & Haveragen (76) tes & & Heusmann tex $0>$ \\
\hline & 2SLS bot sected. & & $\begin{array}{l}\Rightarrow \text { NDA eor } \\
\text { eadocenour }\end{array}$ & & coutry intereeps wast \\
\hline & Priacipal compooents & Priacipal components & 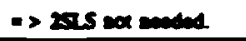 & & the RHS narioles \\
\hline \multirow[t]{2}{*}{ TECHATQUE } & $\operatorname{sols}$ & ad VAR & OLs & & OLS \\
\hline & & & & & $-\cdots$ \\
\hline EXTERNAL OR & Us i mes $(\mu, a t, n)$ & US i nan & i mes - 3 mes Ution & 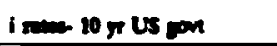 & $\operatorname{los}\left(i \mathrm{us}^{10, t}\right)$ \\
\hline OTR GLOBAL & minus CPI inflation & $Y_{f^{-t r e n d}}$ in $Y_{d^{+}}>\mathrm{PC}$ & (trom 1PS) & (fros ips) & \\
\hline \multirow[t]{3}{*}{ VARUABLES } & L'S ind. produrtion & US return in ach? & & & wine tread \\
\hline & $\angle=>$ ladex of Globel Fuctors & and res ente & & & 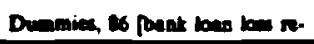 \\
\hline & & & & & enve \& 0 [Brody Mas]. ians. \\
\hline COUNTRY & $\begin{array}{l}\text { P wecood.debt } \\
\text { (Sal Bros.) }\end{array}$ & & $\triangle \mathrm{NDA}$ (IPS) & & \\
\hline \multirow[t]{5}{*}{ VARLABLES } & credit nits (lnit Inv) & & Now GNP change & (chmpe rel to 19:0) & $\log (\mathrm{LT}$ Debt/GNP) \\
\hline & Iocalsumb $* P / E \quad$ (DPC) & & Intemp to mensure & & bet (coman debt/locel Debx) \\
\hline & 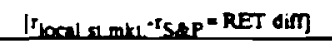 & & expered deprex from & & \\
\hline & Dolack martet premiums & & conual conages not & & \\
\hline & nor sipfieant $(\mathbf{W C}]$ ] & & and & & \\
\hline \multirow[t]{5}{*}{ CONCLUSION } & US facton $\rightarrow$ & dobel fecton -s & 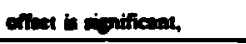 & 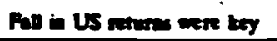 & - 16 rive in US i \\
\hline & betf of nom to LA. & so perceal & $m a x<s$ & 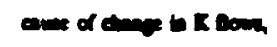 & $p(n) \quad \rightarrow$ \\
\hline & For Asir, cowntry tacron & & whin one geaner & 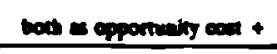 & Corom $1 \%$ all is Pas. \\
\hline & - 3 or 4 \& US fanor & & & E devernienat of wowaty & Inet i wase are the \\
\hline & & & & conitrontinges & wy endying factor \\
\hline
\end{tabular}

Table 1: Econometric Studies of Recent Portfolio Capital Flows 
Table 2

Regressions of Local Interest Rates

Adjusted for Expected Depreciation

(from survey data) against U.S. interest Rates.

(1) (2)

(3)

$\begin{array}{llll}\text { Intercept } & 2.26 & -6.95^{* *} & -0.33 \\ & (3.13) & (2.40) & (1.77) \\ \text { i }_{\text {local }} & 1.4^{* *} & 2.64^{* *} & 1.83^{* *} \\ & (0.49) & (0.37) & (0.28)\end{array}$

Obs.

251

175

234

R-squared

.0274

.2254

.1484

"*: statistically significant at the 99\% level.

Standard errors in parentheses.

Régression 1 excludes Argentina.

Regression 2 excludes both Mexico and Argentina.

Regression 3 excludes Mexico and Argentina only before $6 / 89$. 
Table 2b.

Regressions of Mexican Interest Rates

on US and Domestic Factors

from June 3, 1993 to December 21, 1994

Dependent variables:

(1) CETES

(2) Expected Depreciation

(3) CETES - Expected Depreciation - Tesobonos

(4) Tesobonos - US T-bill

(5) CETES - Expected Depreciation

(6) Tesobonos

(7) CETES - Tesobonos

\begin{tabular}{|c|c|c|c|c|c|c|c|}
\hline Intercept & $\begin{array}{l}(1) \\
13.682^{* *} \\
(1.305)\end{array}$ & $\begin{array}{l}(2) \\
-4.027 \\
(4.925)\end{array}$ & $\begin{array}{l}(3) \\
13.760^{\circ} \\
(5.061)\end{array}$ & $\begin{array}{l}(4) \\
3.607 \% \\
(0.366)\end{array}$ & $\begin{array}{l}(5) \\
16.968^{* 1} \\
(4.812)\end{array}$ & $\begin{array}{l}(6) \\
3.607^{\cdots} \\
(0.366)\end{array}$ & $\begin{array}{l}(7) \\
10.111^{*} \\
(1.17)\end{array}$ \\
\hline$i_{\text {ue }}$ & $\begin{array}{l}-0.070 \\
(0.371)\end{array}$ & $\begin{array}{l}2.286 \\
(1.392)\end{array}$ & $\begin{array}{l}-2.850 \\
(1.430)\end{array}$ & $\begin{array}{l}-0.412 * \\
(0.104)\end{array}$ & $\begin{array}{l}-2.148 \\
(1.360)\end{array}$ & $\begin{array}{l}0.588^{*} \\
(0.104)\end{array}$ & $\begin{array}{l}-0.667^{\circ} \\
(0.333)\end{array}$ \\
\hline Event Dummy & $\begin{array}{c}-1.925^{\circ} \\
(0.472)\end{array}$ & $\begin{array}{l}0.804 \\
(1.833)\end{array}$ & $\begin{array}{l}-1.544 \\
(1.884)\end{array}$ & $\begin{array}{l}-0.805^{*} \\
(0.132)\end{array}$ & $\begin{array}{l}-2.232 \\
(1.791)\end{array}$ & $\begin{array}{l}-0.805^{\circ} \\
(0.132)\end{array}$ & $\begin{array}{l}-1.153^{* *} \\
(0.423)\end{array}$ \\
\hline $\begin{array}{l}\text { F-statistic } \\
\text { R-squared } \\
\text { Adj. R-squared }\end{array}$ & $\begin{array}{l}15.76^{*} \\
.29 \\
.27\end{array}$ & $\begin{array}{l}1.87 \\
.18 \\
.08\end{array}$ & $\begin{array}{l}2.33 \\
.22 \\
.12\end{array}$ & $\begin{array}{l}18.78^{\cdots} \\
.32 \\
.31\end{array}$ & $\begin{array}{l}1.26 \\
.13 \\
.03\end{array}$ & $\begin{array}{l}119.82^{* *} \\
.75 \\
.75\end{array}$ & $\begin{array}{l}3.72^{*} \\
.09 \\
.06\end{array}$ \\
\hline $\begin{array}{l}\text { Durbin-Watson } \\
\text { Nobs. }\end{array}$ & $\begin{array}{l}.22 \\
80\end{array}$ & $\begin{array}{l}1.54 \\
20\end{array}$ & $\begin{array}{l}1.70 \\
20\end{array}$ & $\begin{array}{l}59 \\
81\end{array}$ & $\begin{array}{l}1.77 \\
20\end{array}$ & .55 & $\begin{array}{l}.30 \\
80\end{array}$ \\
\hline
\end{tabular}

First-difference of the observations.

\begin{tabular}{|c|c|c|c|c|c|c|c|}
\hline Intercept & $\begin{array}{l}(1) \\
-.030 \\
(0.101)\end{array}$ & $\begin{array}{l}(2) \\
0.495 \\
(1.187)\end{array}$ & $\begin{array}{l}(3) \\
-1.091 \\
(1.247)\end{array}$ & $\begin{array}{l}(4) \\
0.011 \\
(0.048)\end{array}$ & $\begin{array}{l}(5) \\
-1.047 \\
(1.204)\end{array}$ & $\begin{array}{l}(6) \\
0.011 \\
(0.047)\end{array}$ & $\begin{array}{l}(7) \\
-0.052 \\
(0.109)\end{array}$ \\
\hline$i_{u=}$ & $\begin{array}{l}0.816 \\
(1.233)\end{array}$ & $\begin{array}{l}-2.241 \\
(25.323)\end{array}$ & $\begin{array}{l}24.159 \\
(26.614)\end{array}$ & $\begin{array}{l}-0.724 \\
(0.572)\end{array}$ & $\begin{array}{l}25.688 \\
(25.703)\end{array}$ & $\begin{array}{l}-0.294 \\
(0.571)\end{array}$ & $\begin{array}{l}0.866 \\
(1.33)\end{array}$ \\
\hline Event Dummy & $\begin{array}{l}-0.725^{\circ} \\
(0.351)\end{array}$ & $\begin{array}{l}3.588 \\
(2.219)\end{array}$ & $\begin{array}{l}-4.731^{t} \\
(2.332)\end{array}$ & $\begin{array}{l}-0.474^{*} \\
(0.165)\end{array}$ & $\begin{array}{l}-5.026^{\circ} \\
(2.252)\end{array}$ & $\begin{array}{l}-0.474^{*} \\
(0.165)\end{array}$ & $\begin{array}{r}-0.270 \\
(0.378)\end{array}$ \\
\hline $\begin{array}{l}\text { F-statistic } \\
\text { R-squared } \\
\text { Adjusted R-squared }\end{array}$ & $\begin{array}{l}2.18 \\
.05 \\
.03\end{array}$ & $\begin{array}{l}1.39 \\
.15 \\
.04\end{array}$ & $\begin{array}{l}2.11 \\
.21 \\
.11\end{array}$ & $\begin{array}{l}5.83^{\cdots} \\
.13 \\
.11\end{array}$ & $\begin{array}{l}2.56 \\
.24 \\
.15\end{array}$ & $\begin{array}{l}4.15^{\circ} \\
.10 \\
.07\end{array}$ & $\begin{array}{l}.391 \\
.01 \\
-.02\end{array}$ \\
\hline $\begin{array}{l}\text { Durbin-Watson } \\
\text { Nobs. }\end{array}$ & $\begin{array}{l}1.8 B \\
79\end{array}$ & $\begin{array}{l}2.42 \\
19\end{array}$ & $\begin{array}{l}2.55 \\
19\end{array}$ & $\begin{array}{l}2.15 \\
80^{15}\end{array}$ & $\begin{array}{l}2.59 \\
19\end{array}$ & $\begin{array}{l}2.15 \\
80^{15}\end{array}$ & $\begin{array}{l}2.06 \\
79\end{array}$ \\
\hline
\end{tabular}

+ (*) ["]: statistically significant at the 90\% (95\%) [99\%] level (Standard Errors in Parentheses)

Event Dummy is a variable equal to +1 after the dates of NAFTA approval and the election, and -1 after the times of assassinations, Chiapas uprising, and peso devaluation. Dates for dummy variable were taken as the first observation after the event and effect was cumulative.

Expected Depreciation is unsmoothed. 


\section{Table $3 a$ \\ Regression of Portfolio Capital In Flows \\ on Rates of Return \\ Jan 1987-Mar 1994 (75 obs) \\ (Argentina included, Taiwan excluded)}

(1)

Intercept

$i_{\mathbf{u . g}}$.

$i_{\text {local }}$

$\Delta \mathbf{s}^{\mathbf{e}}$

GDP

\section{Country Effects}

ARG

CHILE

MEX

PHL

KOR
(2)

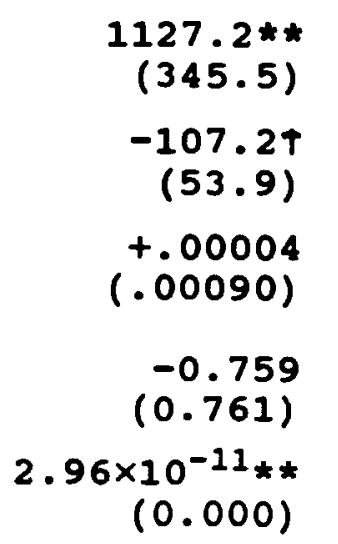

(3)

(4)

$$
\begin{array}{r}
2294.9 * * \\
(373.9) \\
-259.3 * * \\
(61.4) \\
+.00021 \\
(.00113) \\
-0.858 \\
(0.960)
\end{array}
$$

$0.000)$
$1163.2 *$ * (343.6)

-119.7 * $(52.4)$

$-.00019$ $(.00087)$ $2.97 \times 10^{-11 * *}$

$(0.000)$ 
Table 3b.

Regression of Portfolio Capital Inflows on Rates of Return

January 1987 - March 1994

(42 Obs. excluding high-inflation observations)

\begin{tabular}{|c|c|c|c|c|c|c|}
\hline Intercept & $\begin{array}{l}(1) \\
401.4 \\
(136.1)\end{array}$ & $\begin{array}{l}(2) \\
2269.7^{*} \\
(962.0)\end{array}$ & $\begin{array}{l}(3) \\
-234.6 \\
(935.7)\end{array}$ & $\begin{array}{l}(4) \\
-2609.3^{\circ} \\
(976.4)\end{array}$ & $\begin{array}{l}(5) \\
-793.8 \\
(1483.4)\end{array}$ & (6) \\
\hline$i_{\text {us }}$ & $\begin{array}{l}-39.6^{2} \\
(20.2)\end{array}$ & $\begin{array}{l}40.8^{*} \\
(18.6)\end{array}$ & $\begin{array}{l}-41.6 \\
(18.1)\end{array}$ & & & $\begin{array}{l}-62.96 \\
(21.10)\end{array}$ \\
\hline$i_{\text {local }}$ & $\begin{array}{l}0.0005 \\
(.000275)\end{array}$ & $\begin{array}{l}0.000107 \\
(.000255)\end{array}$ & $\begin{array}{l}.00009 \\
(.00024)\end{array}$ & $(.000001)$ & $\begin{array}{l}.000082 \\
(.000250)\end{array}$ & \\
\hline change $s^{e}$ & $\begin{array}{l}-0.24 \\
(0.294)\end{array}$ & $\begin{array}{l}-0.069 \\
(0.275)\end{array}$ & & & & $(.00026)$ \\
\hline $\log$ GDP & & $\begin{array}{l}107.0^{* 1} \\
(38.2)\end{array}$ & $\begin{array}{l}108.8^{* *} \\
(37.1)\end{array}$ & $\begin{array}{l}109.7^{*} \\
(39.1)\end{array}$ & $\begin{array}{l}28.39 \\
(63.60)\end{array}$ & \\
\hline Debt Price & & & & & $\begin{array}{l}3.417 \\
(2.132)\end{array}$ & \\
\hline \multicolumn{7}{|l|}{ Country Effects } \\
\hline Argentina & & & & & & $\begin{array}{l}493.3^{\circ} \\
(199.4)\end{array}$ \\
\hline Chile & & & & & & $\begin{array}{l}561.8^{* *} \\
(201.2)\end{array}$ \\
\hline Mexico & & & & & & $\begin{array}{l}530.4^{t} \\
(277.8)\end{array}$ \\
\hline Philippines & & & & & & $\begin{array}{l}434.6^{* *} \\
(128.0)\end{array}$ \\
\hline Korea & & & & & & $\begin{array}{l}723.0^{* *} \\
(160.1)\end{array}$ \\
\hline $\begin{array}{l}\text { F-Statistic } \\
\text { R-squared } \\
\text { Adjusted R-sq. }\end{array}$ & $\begin{array}{r}1.79 \\
.12 \\
.05\end{array}$ & $\begin{array}{r}3.55^{\circ} \\
.28 \\
.20\end{array}$ & $\begin{array}{c}4.83^{* *} \\
.28 \\
.22\end{array}$ & $\begin{array}{r}4.14^{*} \\
.18 \\
.13\end{array}$ & $\begin{array}{r}3.73^{\circ} \\
.23 \\
.17\end{array}$ & $\begin{array}{c}4.90^{* *} \\
.49 \\
.39\end{array}$ \\
\hline
\end{tabular}

$\dagger(*)\left[{ }^{* *}\right]$ : statistically significant at the $90 \%$ (95\%) [99q] level 
Table 3c. Regression of log Portfolio Capital Inflows on Rates of Return. January 1987 - March 1994

\begin{tabular}{|c|c|c|}
\hline & (1) & (2) \\
\hline \multirow[t]{2}{*}{ Constant } & $-9.578^{\circ *}$ & \\
\hline & $(3.566)$ & \\
\hline \multirow[t]{2}{*}{$i_{u s}$} & $-0.317^{*}$ & $-0.653^{\circ *}$ \\
\hline & $(0.145)$ & $(0.141)$ \\
\hline \multirow[t]{2}{*}{$i_{\text {local }}$} & 0 & $8.8 \times 10^{-7}$ \\
\hline & $(0)$ & $\left(1.9 \times 10^{-6}\right)$ \\
\hline \multirow[t]{2}{*}{$\Delta s^{e}$} & $-0.006^{* *}$ & $-0.007^{* *}$ \\
\hline & $(0.002)$ & $(0.002)$ \\
\hline \multirow[t]{2}{*}{$\log$ GDP } & $0.612^{* *}$ & 0.086 \\
\hline & $(0.118)$ & $(0.13)$ \\
\hline \multicolumn{3}{|c|}{ Country Effects } \\
\hline \multirow[t]{2}{*}{ Argentina } & & $6.695^{+}$ \\
\hline & & (3.863) \\
\hline \multirow[t]{2}{*}{ Chile } & & $6.669^{+}$ \\
\hline & & $(3.951)$ \\
\hline \multirow[t]{2}{*}{ Mexico } & & $8.023^{+}$ \\
\hline & & $(4.206)$ \\
\hline \multirow[t]{2}{*}{ Philippines } & & 3.49 \\
\hline & & (3.709) \\
\hline \multirow[t]{2}{*}{ Korea } & & $7.099^{\dagger}$ \\
\hline & & $(4.07)$ \\
\hline N. Obs. & 76 & 77 \\
\hline Adjusted $\mathrm{R}^{2}$ & .50 & .89 \\
\hline
\end{tabular}


Table 4
Regression of Differential in Expected Rates of Return

Against Portfolio Capital Inflows (log)

\begin{tabular}{|c|c|c|c|c|}
\hline \multirow[b]{2}{*}{ PCI } & \multicolumn{2}{|c|}{ incl. Arg. Mex. } & \multicolumn{2}{|c|}{$\begin{array}{l}\text { excl. high-inflation } \\
\text { obs. for Arg. Mex. }\end{array}$} \\
\hline & $\begin{array}{l}-10.308 \\
(13.526)\end{array}$ & $\begin{array}{r}8.286 \\
(19.771)\end{array}$ & $\begin{array}{l}-.0040 \\
(98.076)\end{array}$ & $\begin{array}{r}5.406 \\
(104.205)\end{array}$ \\
\hline $\begin{array}{l}\text { DEBT } \\
\text { PRICE }\end{array}$ & $\begin{array}{l}-1788.1 \\
(1392.3)\end{array}$ & & & $\begin{array}{r}-625.8 \\
(3609.5)\end{array}$ \\
\hline $\begin{array}{l}\text { country } \\
\text { effects }\end{array}$ & & & & \\
\hline ARG & $\begin{array}{l}57731 * \\
(25834)\end{array}$ & $\begin{array}{l}101795 \\
(42876)\end{array}$ & $\begin{array}{r}203744 * * \\
(61325)\end{array}$ & $\begin{array}{r}21321 \\
(52400)\end{array}$ \\
\hline CHILE & $\begin{array}{r}594.7 \\
(54306.3)\end{array}$ & $\begin{array}{l}107518 \\
(99264)\end{array}$ & $\begin{array}{r}2.186 \\
(68795.20)\end{array}$ & $\begin{array}{r}374.89 \\
(227175)\end{array}$ \\
\hline MEX & $\begin{array}{r}17930 \\
(33805)\end{array}$ & $\begin{array}{r}92706 \\
(67248)\end{array}$ & $\begin{array}{r}19.276 \\
(137127.3)\end{array}$ & $\begin{array}{r}23384 \\
(193607)\end{array}$ \\
\hline PHL & $\begin{array}{r}868.4 \\
(24310.8)\end{array}$ & $\begin{array}{r}92707 \\
(75493)\end{array}$ & $\begin{array}{r}-0.937 \\
(31759.5)\end{array}$ & $\begin{array}{r}32236 \\
(188093)\end{array}$ \\
\hline KOR & $\begin{array}{r}2971.6 \\
(31590.4)\end{array}$ & $\begin{array}{r}176438 \\
(138679)\end{array}$ & $\begin{array}{r}11.66 \\
(48586.80)\end{array}$ & $\begin{array}{r}61041 \\
(355419)\end{array}$ \\
\hline d.f. & 76 & 67 & 42 & 42 \\
\hline $\mathbf{F}$ & .832 & .956 & 1.84 & 1.54 \\
\hline $\mathbf{R}^{2}$ & & .088 & .23 & .24 \\
\hline $\operatorname{adj} \cdot R^{2}$ & & -.004 & .11 & .08 \\
\hline
\end{tabular}

* Statistically significant at 958 level

** Statistically significant at 998 level 
Table 5: Offset Equation

\begin{tabular}{|c|c|c|c|c|}
\hline \multirow{2}{*}{$\begin{array}{l}\text { Dependent variable } \\
\text { ( } \$ \text { millions): }\end{array}$} & \multicolumn{2}{|c|}{ Quarter's Capital Inflow } & \multicolumn{2}{|c|}{ Cumulated Capital Inflow } \\
\hline & (1) & (2) & (3) & (4) \\
\hline \multirow[t]{2}{*}{$\log M$ Base } & $-291.81^{\circ \bullet}$ & & $-2533.84^{\circ *}$ & \\
\hline & $(66.27)$ & & $(335.52)$ & \\
\hline \multirow[t]{2}{*}{$\log$ broad $M$} & & $-204.26^{\circ *}$ & & $-1755.03^{*}$ \\
\hline & & $(45.51)$ & & $(232.60)$ \\
\hline \multirow[t]{2}{*}{$\log$ GDP } & $305.07^{\circ}$ & $299.46^{\circ *}$ & $2522.91^{\circ *}$ & $2453.97^{\circ}$ \\
\hline &.$(52.03)$ & $(50.09)$ & $(263.44)$ & $(256.01)$ \\
\hline \multirow[t]{2}{*}{$i_{u s}$} & $-120.95^{\circ}$ & $-128.86^{\circ}$ & $-799.08^{\circ}$ & $-881.29 *$ \\
\hline & (49.09) & $(46.35)$ & $(248.56)$ & $(236.87)$ \\
\hline \multirow[t]{2}{*}{$\Delta s^{e}$} & $-1.47^{\dagger}$ & -1.08 & -3.48 & -0.01 \\
\hline & $(0.80)$ & $(0.77)$ & $(4.05)$ & $(3.94)$ \\
\hline \multicolumn{5}{|l|}{ Country Effects } \\
\hline \multirow[t]{2}{*}{ Argentina } & 165.92 & $-1335.01^{\circ \bullet}$ & -1985.43 & $-14,897^{\circ}$ \\
\hline & $(292.97)$ & $(411.29)$ & $(1483.39)$ & $(2101.92)$ \\
\hline \multirow[t]{2}{*}{ Chile } & 424.26 & 150.55 & $4051.51^{\circ}$ & 1678.32 \\
\hline & $(380.39)$ & $(371.21)$ & $(1926.00)$ & $(1897.12)$ \\
\hline \multirow[t]{2}{*}{ Mexico } & $470.28^{+}$ & $-880.72^{\dagger}$ & $2351.91^{+}$ & $-9218.68^{\circ *}$ \\
\hline & $(267.54)$ & (457.49) & $(1354.62)$ & $(2338.06)$ \\
\hline \multirow[t]{2}{*}{ Philippines } & -243.32 & $-1883.58^{* *}$ & -792.29 & $-14,997^{\circ}$ \\
\hline & (239.53) & $(380.52)$ & $(1212.80)$ & $(1944.71)$ \\
\hline \multirow[t]{2}{*}{ Korea } & -6.66 & -7.86 & -22.15 & -40.18 \\
\hline & $(265.06)$ & $(262.58)$ & $(1342.04)$ & (1341.94) \\
\hline $\begin{array}{l}\text { Sample } 1987 \text { QI } \\
\text { to: }\end{array}$ & 1993 QII & 1993 QIV & 1993 QII & 1993 QIV \\
\hline N. Obs. & 82 & 84 & 82 & 84 \\
\hline F-statistic & $27.96^{\circ *}$ & $28.49^{\circ "}$ & $46.64^{\circ *}$ & $46.46^{\circ *}$ \\
\hline $\mathbf{R}^{2}$ & .78 & .77 & .85 & .85 \\
\hline Adjusted $\mathrm{R}^{2}$ & .75 & .75 & .83 & .83 \\
\hline
\end{tabular}

'(") ["*]: statistically significant at the $90 \%(95 \%)$ [99\%] level. 